\title{
Evaluation on the Level of Job Satisfaction of Employees at INNCON
}

\author{
Gowtham Aashirvad Kumar,Ravikumar,MonikaGayathiri.
}

\begin{abstract}
The project report subject is job approval and workplace efficiency. The objective is to identify the determinants of job satisfaction and study the connection between job accomplishment and job performance and job satisfaction impact on work presentation. Job satisfaction is described by work characteristics, other persons and private preparations . In order to discover and clarify the documents between life balance and job performance, secondary research information is gathered. However, the overall organisational performance relies on the organization's individual staff performing efficiently and effectively. Therefore, in order to achieve high growth in the organisation, each organisation places significant dependence on their employer performance. Employee effort is an significant factor that will establish a reliability individually. When an worker feels satisfied with the job, he / she is encouraged to make the mental wellbeing grater effort. Then it tends to boost the institution's general efficiency. In other words, the success of the organisation depends on a satisfied individual worker and his effort and skill. Therefore, this study's analysis concern addresses this ; is there an effect on job status from career advancement?main investigate is based on an in-house revise with the application of the hypothetical segment of this thesis between Inncon staff in Chennai. Due to the company-specific nature of the study itself, the findings of this study and the understanding of these outcomes are restricted to this specific business.

Keywords : Inncon,organization.
\end{abstract}

\section{INTRODUCTION}

Every Organization requires mainly basic resources for effective flow around the world the minimum resources are:Man,Money,Machinery,Material.

Every Organization has certain goals or objectives, for accomplishment of those goals or Objectives, the management had to utilize physical and financial resources through the efforts of man. Thus HR is a crucial subsystem in the process of management; HR is also a resource like any natural resource. To management has to get and use these skills, knowledge and ability through development and training and then utilizing them in proper and suitable manner to reach organization goals or objectives.High-level achievement through efficiency and competence has always been a high-priority organizational goal. A high level of concert development of an association is an complete stipulation to do that highly satisfied work force. Satisfied employee contributes to increased work performance effort, then works harder and betterEach organisation therefore attempts to generate a contented workers to function the institution's well-being. However, the overall organisational efficiency relies on the firm's actual staff performing efficiently and effectively Therefore, each organization tries to create a satisfied worker to operate the well-being of the establishment. However, the general organizational effectiveness is based on proactively operating the real employees of the consultancy.

\section{II.DEFINITION FOR JOB SATISFACTION}

Job fulfillment has been distinct as a satisfactory modified state ensuing from evaluating one's job; an sentimental response to one's job; and an approach to one's work. Weiss (2007) claimed productivity is a behavior, but points out that researchers are obviously supposed to delineate items of spatial evaluation that concern (emotion), thoughts, and activities. This description shows that our feelings, views and perceptions from perspectives to our jobs are taken into account.

According to Locke, job satisfaction is a "Pleasurable or positive emotional state resulting from the appraisal of one's job or job experiences".

According to Dubrins, "Job satisfaction is the mount of pleasure or contentment associated with a job. If you like your job intensely, you will experience high satisfaction. If you dislike your job intensely, you will experience job dissatisfaction “.

\section{III.DETERMINANTS OF JOB SATISFACTION}

The various factors influencing job satisfaction may be classified into three categories:-

Individual Factors

Nature of Job

Situational Variables

Individual Factors: Entities from their employment have certain perceptions. If the jobs keep their promises, they will

Revised Manuscript Received on July 22, 2019

Gowtham Aashirvad Kumar Department of Management studies ,Bharath Institute of Higher Education and Research,Chennai,India Ravikumar Department of Management studies,Bharath Institute of Higher Education and Research,Chennai,India

Monica Gayathiri, Department of Management studies,Bharath Institute of Higher Education and Research,Chennai,India. 
feel happy. These requirements are based on the level of training, age, sex, marital status, practice and other variables of an employee.

Level of education: A person's specific educational attainment is a variable determining the degree of career advancement. For instance, many studies discovered a higher education levels and job stability.. The obvious explanation for this occurrence may be that from their work, extremely trained people have very elevated expectations that stay unsatisfied. The premise of Peter, which indicates that each person attempts to achieve his ineptness level, relates faster.[1-5]

Age: In distinct phases of their lives, individuals experience varying degrees of job satisfaction. At the original phase, job satisfaction is high, steadily decreasing. Starts increasing to some degree, and lastly plunging to a small degree. When people enter an organisation, they may have impracticable hypotheses about what they will gain from their job. These hypotheses create them more satisfied. However, when these hypotheses fall short of fact, job satisfaction falls. It begins to rise again as individuals begin to evaluate employment from the right view and proper their hypotheses. Ultimately, especially at the far end of the profession, job fulfillment is declining due to fear of leaving and prospect results.

Sex: One research found women to be less concerned than males because of fewer female job possibilities. But because of their reduced organizational expectations, female employees may be more concerned.

Marital Status: The overall feeling is that, because of their higher duties, married workers and workers with more welfare benefits tend to be more unhappy. But, because they value their employment more than cohabiting employees, such staff may be more comfortable.

Experience: Job security tends to improve with growing years of expertise. But after twenty years of practice, it may reduce, especially between individuals who have not fulfilled their work demands.[6][7][8]

Other Factors: Job security tends to improve with growing years of expertise. But from twenty years of practice, it may reduce, especially between individuals who have not fulfilled their work demands.

Nature of Job: Job nature decides job satisfaction in the form of job level, job material, oversight, fair pay, promotional chance and working group

.Occupational Level: Compared to reduced concentrations, higher-level employment provide more fulfillment. This is because high-level jobs have prestige and status in culture, which becomes a source of fulfillment for the work owners themselves. Professionals, for instance, derive more satisfaction compared to wage-earners: employees in the plant are less satisfied.[9][10]

Job Content: Job information relates to the innate value of the work that relies on the skill necessity and the degree of accountability and development when offered. A greater level of fulfillment of these variables. For instance, a routine and routine work offers less satisfaction: work alignment, job augmentation, and job motivation gradually increase the amount of comfort.[11]

Situational Variables: Working circumstances, especially physical work place, such as workplace circumstances and related work equipment, determine job stability. These are operating in two respects. First, these provide work efficiency adverse connection among education levels, compared to

means. Second, providing these circumstances impacts the understanding of the applicant about the organisation. If these variables are beneficial, people will develop a greater level of job fulfillment.[12][13]

Supervision: As in each form of guidance, the sort of supervision impacts life balance ; the degree of significance given to people differs. There is more priority for persons in employee-oriented oversight, which they perceive as beneficial And they're more satisfied with it. There is more emphasis on job status in job-oriented oversight and individuals become crucial. This condition reduces job satisfaction.[14][15]

Equitable Rewards: The sort of work performance-reward linkage decides the degree of job satisfaction. If the reward is viewed as being based on ability to do the job and fairness, it provides greater satisfaction. It adversely impacts job satisfaction if the benefit is to be viewed on the basis of factors other than job status.

Opportunity for Promotion: It is true that people seek fulfillment in their employment with regard to the nature of work and the workplace, but they also attach significance to the advancement possibilities offered by these employment. If the current work offers promotional opportunities in the future, it will bring more fulfillment. If there is no chance for such advertising, fulfillment will be reduced.[16]

Work Group: Individuals operate in group either officially formed or create themselves to seek intellectual workplace fulfillment. To the extent that these organizations are united ; there is a high level of fulfillment. If the group is not cohesive, there is little job satisfaction. People derive satisfaction from their effective communication within a caring community, and the place of work becomes enjoyable led to job satisfaction.[17]

\section{REVIEW OF LITERATURE}

Concepts of Job Satisfaction, Rewards and Performance In this portion, it describes the main ideas engaged in the study's issue comment. These definitions are job satisfaction, efficiency and organisational incentives. It is the general perception that job satisfaction is an behaviour towards work. In other words, job satisfaction is an intellectual or emotional reaction to the different facets of one's work. A person with a high rate of career advancement has favorable mindsets towards his or her work, while a person who is unhappy with his or her job has adverse behaviours towards his or her job. Luthans (1985) The quotation is a detailed definition provided by Locke. A pleasurable or positive physical state arising from the assessment of one's work or work experience. Job satisfaction is the consequence of employees understanding of how well their work offers those stuff that are considered relevant. Productivity is also described as the repatriation of an individual's awareness of the realization of his or her requirements in relation to his or her work and the surroundings that job satisfaction is a complicated assortment of cognition, feeling and trends.

It is evident from the above terminology that job satisfaction is an unobservable function. There is therefore no distinct way to measure job security. But there are a range of ways in which existing fiction can be recognized.. 
The questionnaire can be used to evaluate job stability. In the questionnaire technique, gratification with the distinct sizes or facets of the work is evaluated and the sum of all contentment results is given as general job pleasure.

(JS).

$\mathrm{JS}=\mathrm{f}$ (Satisfaction with different facets of job)

. Almost any aspect linked to a job can affect a person's level of job satisfaction or discontent. There are a myriad of factors that have an impact on job satisfaction. The main ones can be summed up by recalling the characteristics of job satisfaction. They are pay, the work itself, promotions, supervision,workgroup, and working conditions (Luthans 1985).

Almost every element of a job can influence a person's amount of job satisfaction or dissatisfaction. There are a number of variables that have an effect on job satisfaction. The primary ones can be summarized by recalling the features of job satisfaction. When evaluating job satisfaction results, it is essential to break down the assessment into a sequence of particular factors. These include efficiency, revenue, absences and other impacts (fatalities, frustrations, overall health).

The main objective of reward programs are attract qualified people to join the organization to keep employees coming to work and to motivate employees to achieve high level of performance. Though the rewards are provided by the organization, they are evaluated by the individual. To the extent that the rewards are adequate and equitable, the individual achieves a level of satisfaction. her willing to work when staff are happy with their job and meet their requirements, create an connection to work, or we say that they make an motivation to play better. Enhanced action results in performance improvement.

Job Satisfaction and Performance Relationship

The connection among job satisfaction and achievement was creatively evaluated in a multitude of organisational environments. The results of these research were mixed. Cummings (1970) recognized three main points of perspective on this partnership.. Pleasure leads performance, success causes satisfaction, and benefits give rise to both appearance and fulfilment. Both of these three viewpoints are backed by a variety of investigationsMirvis and Lawer (1977) generated conclusive results on the connection between job satisfaction and results. In trying to assess the efficiency of bank tellers in terms of money shortages, their arguments are satisfied that tellers were less likely to demonstrate shortages and less likely to quit their employment. Kornhanuserand Sharp (1976) More than thirty studies have been performed to determine the connection between satisfaction and performance in the manufacturing industry. Many study have discovered that there is a positive relationship between job satisfaction and attainment. Katzell, Barret and Porker (1952) established that work satisfaction was neither correlated with turnover nor with the quality of manufacturing.

\section{V.RESEARCH METHODOLOGY}

\section{A. Significance of the study}

In today's competitive world especially after the advent of liberalization, privatization and globalization employment opportunities in the private sector has gone up. People are constantly on the move and are shifting to different companies
Effort is the inner strength of a individual who makes him or

as and when they get better offers. So it is becoming increasingly difficult for the organizations, to retain employees for longer duration. The study helps the organization to identify the positive and negative aspects as perceived by the employees and thereby take suitable steps to meet their expectation and thereby increase the approval level of such employee.

The study helps the association to identify the positive and negative aspects as perceived by the employees and thereby take suitable steps to meet their expectation and increase the satisfaction level of them. This study is being done to know the satisfaction level of employees of Inncon. The finding of the study will throw a light on the extent of satisfaction of the employees. The management can work on areas where there are problems and make Inncon, a wonderful organization to work for. This study is to analyze the factors that are to be identified and considered to play an important role in Job satisfaction among the employees. The researcher aims to identify and highlight the difference in perception among employees of different demographic characteristics and suiting their expectations.

\section{VI.OBJECTIVES OF THE PROJECT}

Primary objective:

To study the level of Job satisfaction of employees in Inncon, Chennai

Secondary objectives:

To determine the perception of employees about their Enrichment of Job

To analyze the stress factors among the employees

To examine the factors those improve the satisfaction level of employees at workplace

To offer valuable suggestions to the management of Inncon to improve the overall satisfaction level of employees[18]

\section{VII.RESEARCH DESIGN}

Exploratory research surveys are those which are deemed to be a problem or situation inquiry that offers ideas to the investigator. Research is intended to provide details where there is a tiny quantity of data available. It may use a range of techniques, such as trial research, interviews, group conversations, experiments, or other tactics, to obtain data.

Survey Method is used to study "Job Satisfaction between Employees." Surveys are worried with the description, recording, analysis and interpretation of either existing or existing circumstances. Surveys are generally suitable for social and behavioral sciences. Surveys may be either a census or a sample survey. It occurs that the technique of in sequence collection is either observation, or interview, orquestionnaire/opinionnaire or some projective technique(s).[19]

\section{METHOD OF COLLECTION OF DATA}

The data relates to data or to facts. Researchers often see information as merely a numerical figure. It also contains descriptive facts, numerical data, qualitative and quantitative data. 
Data collection is an significant phase in studies. In reality, the quality of the information gathered is determined by the amount of the studies.

Collection of data is done by 2 methods.

Primary Data

Main data is also known as information gathered for the first time in the field survey. Such information shall be gathered with a particular set of goals for assessing the current status of any parameter explored.

Secondary data

The secondary data required for my research was gathered from the company system..[20]

\section{IX.TYPE OF QUESTIONNAIRE}

The technique used for information collection was the "Questionnaire technique" which is constructed as one. It's a combination of open-ended and closed-ended and multiple decisions. The words used were easy and help prevent uncertainty and miscommunication between the participants. There are only two options of responses to these issues. In reality, these issues do not provide a lot of data about the issue. However, these issues are fast and simple for scientists to finish the assignment.[21]

\section{X.SAMPLING METHOD}

Sampling procedure: Convenience sampling Sample size: 120

Sampling Unit:Employees in Inncon, Chennai

\section{XI.LIMITATIONS}

- It's not very hard to obtain main information because of gathering individuals on their busy timetable.

- Human element is a significant limitation• Workers may be unwilling to disclose essential data.

- The perspectives derived from the research carried out can not be taken as the view of the entire community.

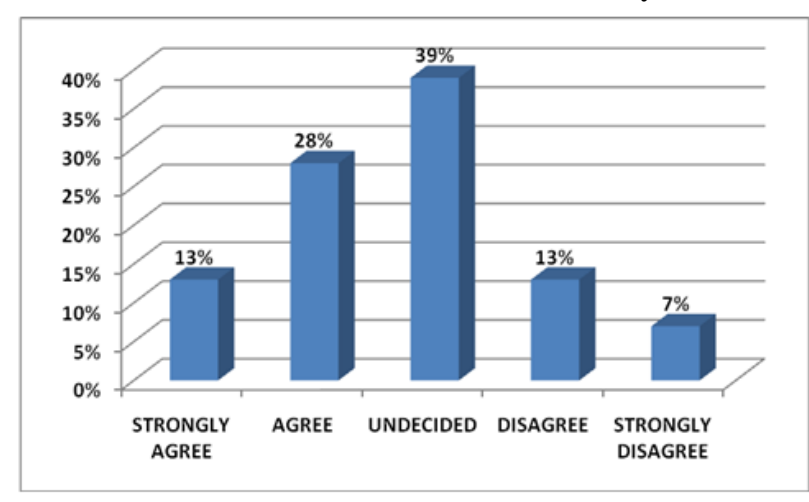

Fig.1

\section{INFERENCE:}

13 per cent of participants highly agree that their director and superior trust each other, 28 per cent agree, 39 per cent do not agree or disagree, 13 per cent disagree, and the remaining 7 per cent highly disagree.

TABLE: 1 SUPERVISOR LISTENS TO SUBORDINATE IDEAS

\begin{tabular}{||l||l||l||}
\hline OPTIONS & $\begin{array}{l}\text { NO } \\
\text { RESPONDENTS }\end{array}$ & PERCENTAGE \\
\hline \hline STRONG AGREE & 3 & $3 \%$ \\
\hline \hline AGREE & 62 & $52 \%$ \\
\hline \hline UNDECIDED & 14 & $12 \%$ \\
\hline \hline DISAGREE & 13 & $10 \%$ \\
\hline \hline STRONGLY \\
DISAGREE & 28 & $23 \%$ \\
\hline TOTAL & $\mathbf{2 0}$ & $\mathbf{1 0 0} \%$ \\
\hline
\end{tabular}

Fig.2SUPERVISOR LISTENS TO SUBORDINATE IDEAS

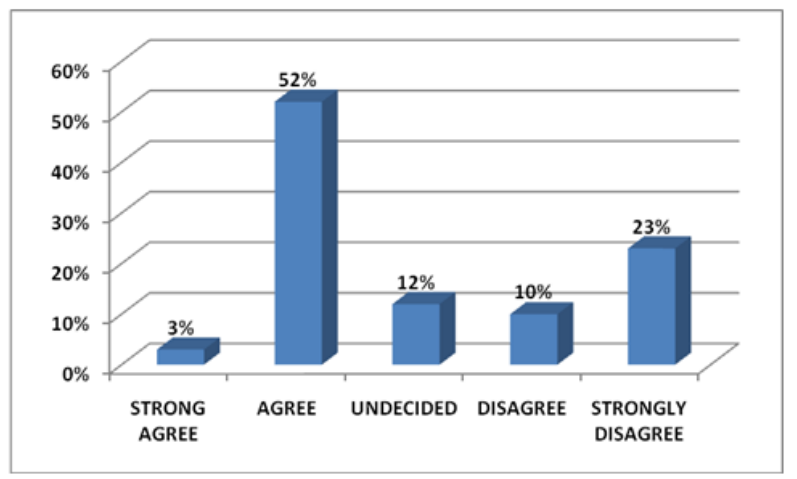

INFERENCE:

$3 \%$ of participants highly agree that their manager listens to his subordinates ' thoughts, 52 percent agree, 12 percent disagree or oppose, 10 percent disagree, and the remaining 23 percent highly object.

TABLE:2SUPERVISORS WELCOMES CRITICISMS FROM HIS SUBORDINATES

\begin{tabular}{||l||l||l||}
\hline OPTIONS & NO OF RESPONDENTS & PERCENTAGE \\
\hline \hline STRONGLY AGREE & 0 & $0 \%$ \\
\hline \hline AGREE & 0 & $0 \%$ \\
\hline \hline UNDECIDED & 0 & $0 \%$ \\
\hline \hline DISAGREE & 0 & $0 \%$ \\
\hline \hline STRONGLY DISAGREE & 120 & $100 \%$ \\
\hline \hline TOTAL & $\mathbf{1 2 0}$ & $\mathbf{1 0 0} \%$ \\
\hline
\end{tabular}

Fig.3SUPERVISORS WELCOMES CRITICISMS FROM HIS SUBORDINATES

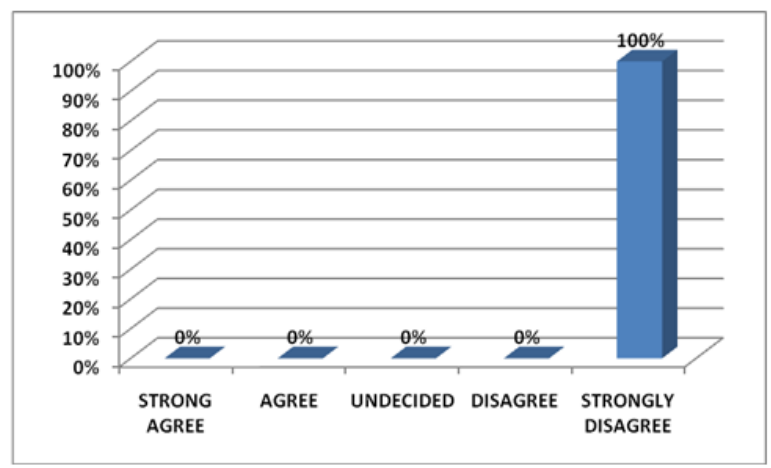

INFERENCE:

$100 \%$ of the respondents strongly disagree that their supervisor welcomes criticisms from hisSubordinates. 
TABLE:3 SUPERVISORS

CRITICISMS ABOUT HIS/HIS

GIVES SUBORDINATE WORK

\begin{tabular}{||l||l||l||}
\hline OPTIONS & $\begin{array}{l}\text { NO } \\
\text { RESPONDENTS }\end{array}$ & PERCENTAGE \\
\hline \hline STRONGLY AGREE & 16 & $13 \%$ \\
\hline \hline AGREE & 18 & $15 \%$ \\
\hline \hline UNDECIDED & 76 & $64 \%$ \\
\hline \hline DISAGREE & 4 & $3 \%$ \\
\hline \hline STRONGLYDISAGREE & 6 & $5 \%$ \\
\hline \hline TOTAL & $\mathbf{1 2 0}$ & $\mathbf{1 0 0} \%$ \\
\hline
\end{tabular}

Fig 4.SUPERVISORS GIVES NEGATIVE CRITICISMS ABOUT HIS/HER SUBORDINATES WORK

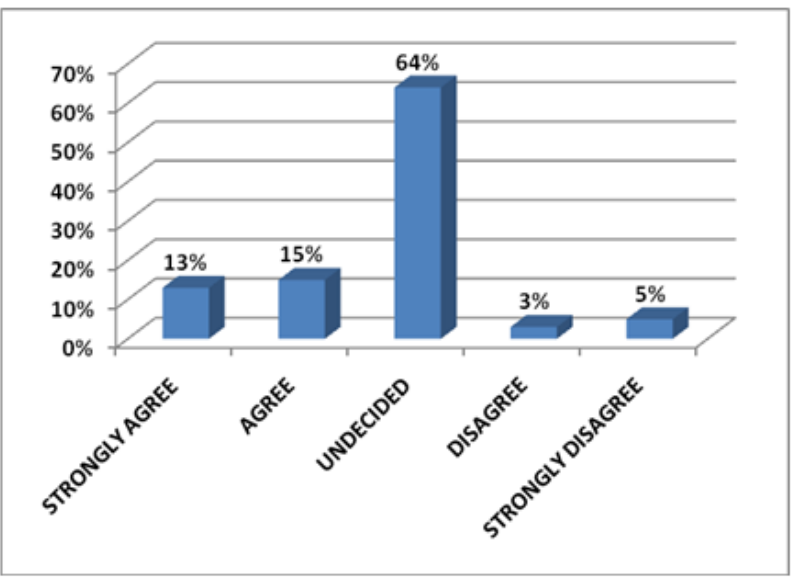

INFERENCE $13 \%$ of the respondents strongly agree that their supervisor gives negative criticisms about his/her subordinates work, $15 \%$ of respondents agree this, $64 \%$ of them neither agree nor disagree this, $3 \%$ of them disagree and the rest $5 \%$ of them strongly disagree this.[22] DURING WORK HOURS

\begin{tabular}{|l||l||l||}
\hline OPTIONS & $\begin{array}{l}\text { NO } \\
\text { RESPONDENTS }\end{array}$ & OF \\
\hline STRONGLY AGREE & 55 & $46 \%$ \\
\hline AGREE & 58 & $48 \%$ \\
\hline UNDECIDED & 6 & $5 \%$ \\
\hline DISAGREE & 1 & $1 \%$ \\
\hline STRONGLY DISAGREE & 0 & $0 \%$ \\
\hline TOTAL & 120 & $\mathbf{1 0 0} \%$ \\
\hline
\end{tabular}

Fig.5SUBORDINATE MEETING OF SUPERVISOR DURING WORK HOURS

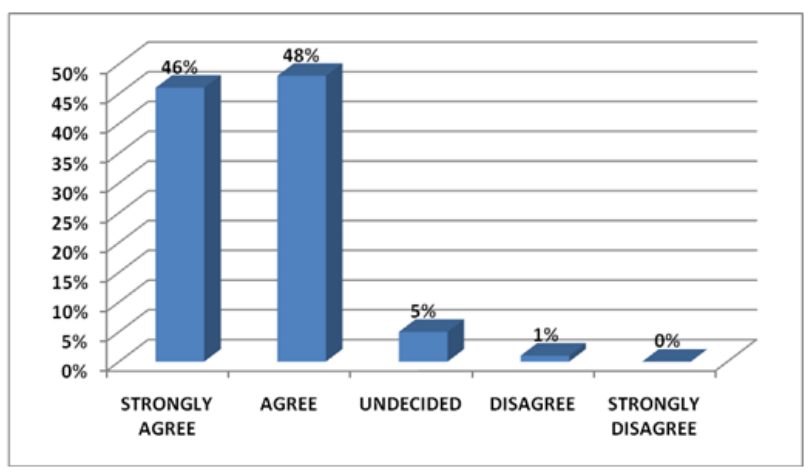

\section{INFERENCE:}

$46 \%$ of the respondents strongly agree that they hardly meet their supervisor during work hours, $48 \%$ of respondents agree
TABLE:4SUBORDINATE MEETING OF SUPERVISOR

this, $5 \%$ of them neither agree nor disagree this, and the rest $1 \%$ of them disagree.

TABLE:5SUPERVISOR COMMUNICATIONS TO SUBORDINATES

\begin{tabular}{|l||l||l||}
\hline OPTIONS & NO OF RESPONDENTS & PERCENTAGE \\
\hline \hline EXCELLENT & 14 & $12 \%$ \\
\hline \hline GOOD & 70 & $58 \%$ \\
\hline \hline AVERAGE & 24 & $20 \%$ \\
\hline \hline POOR & 7 & $6 \%$ \\
\hline VERY POOR & 5 & $4 \%$ \\
\hline \hline TOTAL & $\mathbf{1 2 0}$ & $\mathbf{1 0 0} \%$ \\
\hline
\end{tabular}

Fig.6SUPERVISOR SUBORDINATES

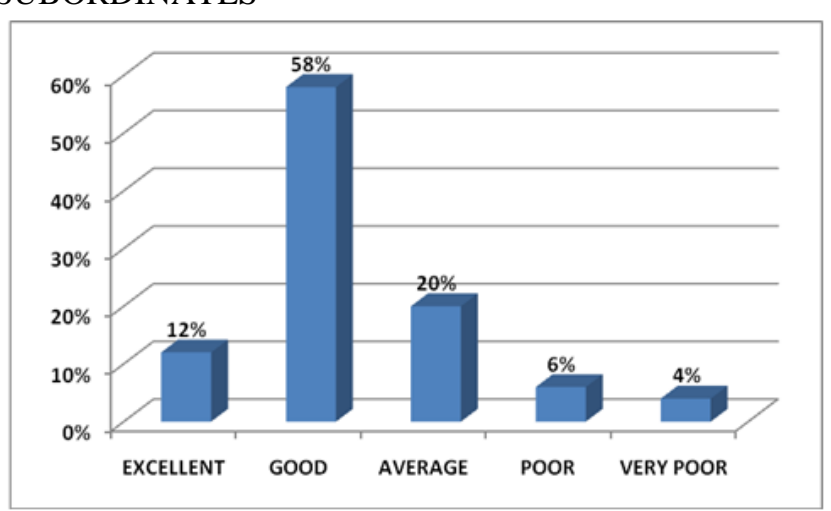

INFERENCE: $12 \%$ of the respondents feel that the effectiveness of supervisor in communication is excellent, $58 \%$ said ii is good, $20 \%$ said it is average, $6 \%$ said it is poor and for the rest $4 \%$ it is very poor

TABLE:6.SUPERVISOR'S MOTIVATION OF PEOPLE

\begin{tabular}{|l|l|l||}
\hline OPTIONS & NO OF RESPONDENTS & PERCENTAGE \\
\hline EXCELLENT & 13 & $11 \%$ \\
\hline GOOD & 61 & $51 \%$ \\
\hline AVERAGE & 29 & $24 \%$ \\
\hline POOR & 13 & $11 \%$ \\
\hline VERY POOR & 4 & $3 \%$ \\
\hline TOTAL & $\mathbf{1 2 0}$ & $\mathbf{1 0 0} \%$ \\
\hline
\end{tabular}

Fig.7SUPERVISOR'S MOTIVATION OF PEOPLE
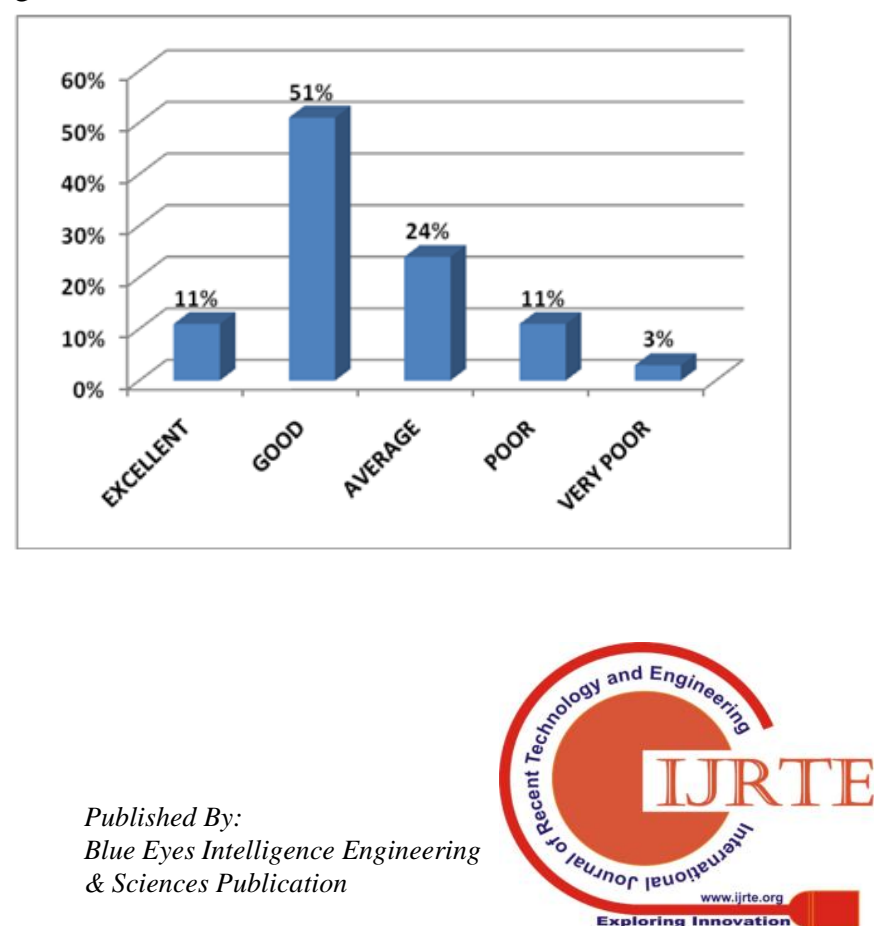


\section{INFERENCE:}

$11 \%$ of the respondents said the effectiveness of supervisor in motivation is excellent, $51 \%$ good, $24 \%$ said it is average, $11 \%$ said it is poor and for the rest $2 \%$ it is very good.[23]

\begin{tabular}{||l||l|l||}
\hline \multicolumn{1}{||l||}{ OPTIONS } & NO OF RESPONDENTS & PERCENTAGE \\
\hline \hline EXCELLENT & 8 & $7 \%$ \\
\hline \hline GOOD & 17 & $14 \%$ \\
\hline \hline AVERAGE & 12 & $10 \%$ \\
\hline \hline POOR & 49 & $41 \%$ \\
\hline \hline VERY POOR & 34 & $28 \%$ \\
\hline \hline TOTAL & $\mathbf{1 2 0}$ & $\mathbf{1 0 0} \%$ \\
\hline
\end{tabular}

TABLE:7.SUPERVISOR UNDERSTANDING OF SUBORDINATESGRIEVANCES' Fig:8SUPERVISOR UNDERSTANDING OF SUBORDINATES

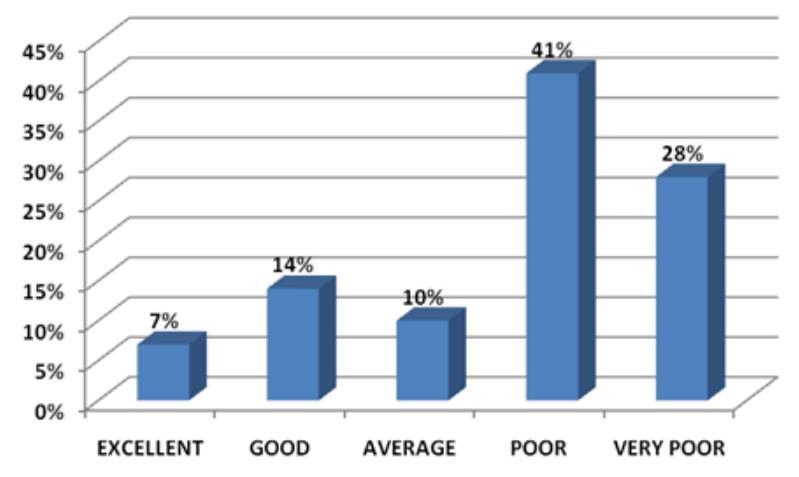

\section{INFERENCE:}

$7 \%$ of the respondents feel that their supervisor is excellent in uunderstanding of his subordinates grievances', $14 \%$ said it is good, $10 \%$ said it is average, $41 \%$ said it is poor and for the rest $28 \%$ it is very poor.

TABLE:8 CHI SQUARE TEST

Chi-Square between involvement of the respondents and their feeling on complaint taking care of system in the organization

To discover the unwavering quality of the gathered information Chi-square test must be directed, required theory is the invalid speculation

Invalid Hypothesis:

Ho $=$ There is no reliance between experience of the respondents and their sentiment on complaint taking care of instrument in the organization

Exchange Hypothesis:

$\mathrm{H} 1=$ There is a reliance between experience of the respondents and their sentiment on complaint dealing with system in the organization

\section{TABLE: 9 OBSERVED FREQUENCY}

FORMULA:

CHI SQUARE $=\sum[(\mathrm{O}-\mathrm{E}) 2 / \mathrm{E}]$

$\mathrm{O}$ - Observed frequency

E- Expected frequency

\begin{tabular}{|l|l|l|l|l|l|}
\hline Experience/Grievance & $\begin{array}{l}< \\
\text { Yrs }\end{array}$ & $\begin{array}{l}\mathbf{6 - 1 0} \\
\text { Yrs }\end{array}$ & $\begin{array}{l}\text { 11-15 } \\
\text { Yrs }\end{array}$ & $\begin{array}{l}>\quad 15 \\
\text { Yrs }\end{array}$ & Total \\
\hline Excellent & 3 & 3 & 0 & 0 & $\mathbf{6}$ \\
\hline Good & 32 & 25 & 2 & 1 & $\mathbf{6 0}$ \\
\hline Average & 23 & 18 & 2 & 0 & $\mathbf{4 3}$ \\
\hline Poor & 2 & 2 & 0 & 0 & $\mathbf{4}$ \\
\hline Very Poor & 4 & 2 & 1 & 0 & 7 \\
\hline Total & $\mathbf{6 4}$ & $\mathbf{5 0}$ & $\mathbf{5}$ & $\mathbf{1}$ & $\mathbf{1 2 0}$ \\
\hline
\end{tabular}

TABLE: 10.EXPECTED FREQUENCY:

\begin{tabular}{|l|l|l|l|l|l|}
\hline Experience/Grievance & $\begin{array}{l}\mathbf{5} \\
\text { Yrs }\end{array}$ & $\begin{array}{l}\mathbf{6 - 1 0} \\
\text { Yrs }\end{array}$ & $\begin{array}{l}\mathbf{1 1 - 1 5} \\
\text { Yrs }\end{array}$ & $\begin{array}{l}>\quad \mathbf{1 5} \\
\text { Yrs }\end{array}$ & Total \\
\hline Excellent & 3.20 & 2.50 & 0.25 & 0.05 & $\mathbf{6}$ \\
\hline Good & 32.00 & 25.00 & 2.50 & 0.50 & $\mathbf{6 0}$ \\
\hline Average & 22.93 & 17.92 & 1.79 & 0.36 & $\mathbf{4 3}$ \\
\hline Poor & 2.13 & 1.67 & 0.17 & 0.03 & $\mathbf{4}$ \\
\hline Very Poor & 3.73 & 2.92 & 0.29 & 0.06 & $\mathbf{7}$ \\
\hline Total & $\mathbf{6 4}$ & $\mathbf{5 0}$ & $\mathbf{5}$ & $\mathbf{l}$ & $\mathbf{1 2 0}$ \\
\hline
\end{tabular}

TABLE:11CHI-SQUARE CALCULATION TABLE

Table- II: Name of the Table that justify the values

\begin{tabular}{|c|c|c|c|c|}
\hline $\mathbf{O}$ & $\mathbf{E}$ & O-E & $\begin{array}{l}\text { (O-E } \\
)^{2}\end{array}$ & $\begin{array}{l}(\mathrm{O}-\mathrm{E})^{2} / \\
\mathrm{E}\end{array}$ \\
\hline 3 & 3.20 & -0.20 & 0.04 & 0.01 \\
\hline 3 & 2.50 & 0.50 & 0.25 & 0.10 \\
\hline 0 & 0.25 & -0.25 & 0.06 & 0.25 \\
\hline 0 & 0.05 & -0.05 & 0.00 & 0.05 \\
\hline 32 & 32.00 & 0.00 & 0.00 & 0.00 \\
\hline 25 & 25.00 & 0.00 & 0.00 & 0.00 \\
\hline 2 & 2.50 & -0.50 & 0.25 & 0.10 \\
\hline 1 & 0.50 & 0.50 & 0.25 & 0.50 \\
\hline 23 & 22.93 & 0.07 & 0.00 & 0.00 \\
\hline 18 & 17.92 & 0.08 & 0.01 & 0.00 \\
\hline 2 & 1.79 & 0.21 & 0.04 & 0.02 \\
\hline 0 & 0.36 & -0.36 & 0.13 & 0.36 \\
\hline 2 & 2.13 & -0.13 & 0.02 & 0.01 \\
\hline 2 & 1.67 & 0.33 & 0.11 & 0.07 \\
\hline 0 & 0.17 & -0.17 & 0.03 & 0.17 \\
\hline 0 & 0.03 & -0.03 & 0.00 & 0.03 \\
\hline 4 & 3.73 & 0.27 & 0.07 & 0.02 \\
\hline 2 & 2.92 & -0.92 & 0.84 & 0.29 \\
\hline 1 & 0.29 & 0.71 & 0.50 & 1.72 \\
\hline 0 & 0.06 & -0.06 & 0.00 & 0.06 \\
\hline
\end{tabular}


$(\mathrm{O}-\mathrm{E})=$ Difference between observed frequency and expected frequency.

$(\mathrm{O}-\mathrm{E}) 2=$ Square of the difference

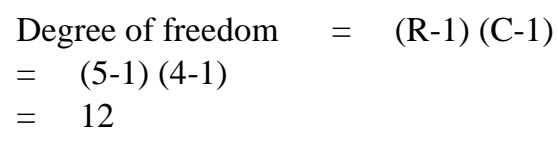

At $5 \%$ level of significance the table value is 21.026

Calculated value $\quad=3.76$

Table value $>$ calculated value

H0 is accepted.

Inference:

Hence it is proved by the calculation that there is no significant relationship betweenexperience of the respondents and their opinion on grievance handling mechanism in the company[24]

\section{XII.RESULTS}

$2 \%$ of the respondents are under 20 years of age, $34 \%$ are in the age gathering of $21-30$ years, $46 \%$ of them are in $31-40$ years and $18 \%$ of the respondents are under 40 years of age.

$\bullet 97 \%$ of the complete respondents are male and the rest $3 \%$ are female

$\cdot 82 \%$ of the complete respondents are graduates, $1 \%$ of them are post graduate, $16 \%$ of them are certificate holders and the rest $1 \%$ of the respondents are having other capability.

$.9 \%$ of respondents are overseers, $47 \%$ of them are security staffs and the rest $44 \%$ of them are housekeeping staffs [25-29]

-3\% of the respondents are under 5 years experienced, $42 \%$ of respondents are having 6-10 years of experience, $4 \%$ of them are having 11-15 years of experience and the rest $1 \%$ of them are having over 15 years experience

$\cdot 27 \%$ of the respondents emphatically concur that their chief is steady, $56 \%$ of respondents concur this, $9 \%$ of them neither concur nor differ this, $5 \%$ of them differ and the rest $3 \%$ of them unequivocally differ this.

$\cdot 24 \%$ of the respondents emphatically concur that their chief has great working association with his subordinates, $58 \%$ of respondents concur this, $9 \%$ of them neither concur nor differ this, $5 \%$ of them differ and the rest $4 \%$ of them firmly differ this.

$.9 \%$ of the respondents emphatically concur that their chief shows care and worry to his subordinates, $53 \%$ of respondents concur this, $14 \%$ of them neither concur nor differ this, $17 \%$ of them differ and the rest $7 \%$ of them firmly differ this.

$\cdot 12 \%$ of the respondents emphatically concur that their administrator never show prejudice in treating his subordinates, $57 \%$ of respondents concur this, $12 \%$ of them neither concur nor differ this, $14 \%$ of them differ and the rest $5 \%$ of them firmly differ this.
-13\% of the respondents unequivocally concur that their administrator and subordinate trust one another, $28 \%$ of respondents concur this, $39 \%$ of them neither concur nor differ this, $13 \%$ of them differ and the rest $7 \%$ of them emphatically differ this. [30]

-3\% of the respondents unequivocally concur that their administrator tunes in to his subordinates thoughts, $52 \%$ of respondents concur this, $12 \%$ of them neither concur nor differ this, $10 \%$ of them differ and the rest $23 \%$ of them emphatically differ this.

-100\% of the respondents unequivocally differ that their administrator invites reactions from his subordinates

-13\% of the respondents unequivocally concur that their administrator gives negative reactions about his/her subordinates work, $15 \%$ of respondents concur this, $64 \%$ of them neither concur nor differ this, $3 \%$ of them differ and the rest $5 \%$ of them emphatically differ this.

- $46 \%$ of the respondents unequivocally concur that they barely meet their chief during work hours, $48 \%$ of respondents concur this, $5 \%$ of them neither concur nor differ this, and the rest $1 \%$ of them oppose this idea [31]

$\cdot 12 \%$ of the respondents feel that the viability of administrator in correspondence is magnificent, $58 \%$ said ii is great, $20 \%$ said it is normal, $6 \%$ said it is poor and for the rest $4 \%$ it is poor.

-11\% of the respondents said the viability of administrator in inspiration is magnificent, $51 \%$ great, $24 \%$ said it is normal, $11 \%$ said it is poor and for the rest $2 \%$ it is poor.

- $7 \%$ of the respondents feel that their director is superb in uunderstanding of his subordinates complaints', $14 \%$ said it is great, $10 \%$ said it is normal, $41 \%$ said it is poor and for the rest $28 \%$ it is poor.

$-10 \%$ of the respondents feel that their director is superb in disposition towards subordinates, $55 \%$ said it is great, $24 \%$ said it is normal, $10 \%$ said it is poor and for the rest $1 \%$ it is poor.

-5\% of the respondents feel that their administrator is brilliant in ggrievances dealing with, half said it is great, $36 \%$ said it is normal, $3 \%$ said it is poor and for the rest $6 \%$ it is poor.

-33\% of the respondents feels neatness of association is brilliant, half of the respondents feel better, $12 \%$ feel normal, $1 \%$ of the respondent feel poor and $4 \%$ of the respondents feel poor.[32] 


\section{XIII.DISCUSSIONS}

The suggestions are based on the factors that were found to be an important aspect of a women employee's job satisfaction. It was found that Work culture is the most important factor responsible for an employee's job satisfaction. Though most of the variables associated with the work culture were satisfactory in the insurance sector but there are a few grey areas which need to be looked into. These are as following:

- Women employees were dissatisfied because of nonexistence of job security in the organization

- They were also dissatisfied on the closed and non-friendly work atmosphere.

- No work flexibility with respect to family responsibilities.

- The negative communication flow with their superiors

- Unrealistic targets

Therefore organizations should make sure that the employees feel part of the organization.

- Communication should be encouraged between employees and superiors.

- Help people feel that they are part of something bigger than themselves and their individual job. This can be done by keeping workers well informed about the events happening around them.

- They should be able to put their views forth.

- Respect and fear are two very different aspects so superiors should act in a friendly way so that the workers respect them and are not scared of them.

- Targets should be set in view of business expansion but innovative schemes like cash reward for best performers, fun and food nights etc should be arranged so that the workers do not feel that extra pressure and feel satisfied after achieving their targets. In short the organizations should celebrate achievements in pride.

- Organizations can also start exercises or fun breaks at work to reduce the stress level in employees.

- Organizations should promote a fair balance between work and personal life and should make sure that senior managers model the same behaviour.

- Employees should feel a certain amount of security for their job and should be reassured about this fact.

Pay for performance

- This is the second important factor. The only dissatisfying factor here was that employee felt that they were not being paid according to their performance, abilities and competencies.

- Women staff were more happy when they think that they are being properly compensated for the job they do. Institutions should then contemplate the duties of staff, the energy they have made, the work they have accomplished well and the requirements of their employment.

- Ensure that rewards are for a real response to the organization

- There should be consistency in the policy on rewards

- If the wage is viable, make sure that the staff know about this now.

- Rewards may include a range of privileges and advantages other than cash.
Growth and recognition

- Women employees are more satisfied when they have growth opportunities. This includes chances to learn and grow and getting opportunities to enhance one's skills. Insurance industry offers good growth opportunities but for further boosting up the satisfaction level

- Organizations should promote from within whenever possible[33]

- Review work periodically to remove unnecessary red-tapism

- Reward promising employees with roles on interesting projects.

Authority

Women employees are more satisfies when they have authority to do their work freely and they are invited in the decision making process.

- When reasonable let employees take the decision

- Allow employees to give input on decisions that will affect them

- Establish work goals but let employees decide how they will achieve those goals. Later reviews may help to identify innovative, best work techniques.

- Manage the number of interruptions a person faces while trying to complete his task. So that he is not frustrated by unnecessary obstructions in his path towars accomplishing his goals.

- For innovative ideas and feedbacks such Questions could be asked like "If there were just one or two decisions that you could make, which ones would make the biggest difference in your jobs?"

\section{XIV.CONCLUSION}

From the study results shows that women employees of Inncon, Chennai are satisfied with the employer relationship, working condition, welfare and benefits and communication from the top management. Nevertheless, the dissatisfaction expressed by few employees also has to be taken in to consideration.

An all round pleasing, conducive environment creates better public relations as well as happier human relations.

Inncon has highly satisfied women employees whose level of satisfaction is high. With an extra focus on a few areas which is required to maintain the satisfaction level of the employees, could become an excellent employee oriented organisation.

\section{REFERENCES}

1) BharthVajan R., Ramachandran S.,Psychographic dimensions of training,2016,International Journal of Pharmacy and Technology,V-8,I-4,P-23727-23729

2) Balakrishnan P., Bharthvajan R.,A study on human resource planning in hospitals in Chennai City,2014,International Journal of Applied Engineering Research,V-9,I-22,P-7503-7507

3) Priyadarsini P., Bharthvajan R.,Role of emotional intelligence training programme in reducing the stress of the nurses,2014,International Journal of Applied Engineering Research,V-9,I-22,P-7411-7421

Published By:

Blue Eyes Intelligence Engineering \& Sciences Publication 
4) Kerinab Beenu G., Bharthvajan R.,Empirical analysis on the cosmetic buying behavior of young women in South India,2014,International Journal of Applied Engineering Research,V-9,I-22,P-7361-7366

5) Balakrishnan P., Bharthvajan R.,Whistling in the wind,2014,International Journal of Applied Engineering Research,V-9,I-22,P-7586-7593

6) Krishnan B., Peter M.,Health hazards of Indian Bpo employee-an alarming issue,2014,International Journal of Applied Engineering Research,V-9,I-22,P-7336-7341

7) Kerinab Beenu G.H., Peter M.,Role of insurance in economic development,2014,International Journal of Applied Engineering Research,V-9,I-22,P-7532-7539

8) Balakrishnan P., Peter M., Priyadarsini P.,Efficiency of safety measures for wellbeing of employees in manufacturing industry,2014,International Journal of Applied Engineering Research,V-9,I-22,P-7376-7382

9) Anbarasi M., Praveen Kumar S.,Online sales promotions of herbal products and its effectiveness towards tanisha.com,2019,Indian Journal of Public Health Research and Development,V-10,I-1,P-195-200

10) Anbarasi M., Praveen Kumar S.,Various online marketing and promotions strategies to improve the validation towards the organic products in the pharmaceutical sectors,2019,Indian Journal of Public Health Research and Development,V-10,I-1,P-263-269

11) Loganathan R., Praveen Kumar S.,Grievance handling a key factor for solving issues of employees in an organization,2014,International Journal of Applied Engineering Research,V-9,I-22,P-7483-7491

12) Loganathan R., Praveen Kumar S.,Study on preference of private label brands in super and Hypermarkets,2014,International Journal of Applied Engineering Research,V-9,I-22,P-7327-7335

13) Smitha M., Praveen Kumar S.,Understanding stress and its managementamong the nurses in Chennai city,2014,International Journal of Applied Engineering Research,V-9,I-22,P-7560-7565

14) Kerinab Beenu G.H., Praveen Kumar S.,A study on the investment behavior of Chennai investors in mutual fund schemes,2014,International Journal of Applied Engineering Research,V-9,I-22,P-7520-7525

15) Loganathan R., Praveen Kumar S.,Retention strategies key for organizational productivity,2014,International Journal of Applied Engineering Research,V-9,I-22,P-7443-7447

16) Pavithra J., Ganesan M., Brindha G.,State wise analysis of microfinance sector in India,2016,International Journal of Pharmacy and Technology,V-8,I-4,P-23417-23432

17) Pavithra J., Ganesan M.,A comparative study on microfinance in India and abroad,2016,International Journal of Applied Business and Economic Research,V-14,I-8,P-5471-5476

18) Pavithra J., Ganesan M.,A study on awareness and impact of micro-financial schemes,2016,International Journal of Applied Business and Economic Research,V-14,I-8,P-5449-5460

19) Senthilmurugan P., Pavithra J.,Consumer preference towards organised retailing with reference to Big Bazaar,2014,International Journal of Applied Engineering Research,V-9,I-22,P-7469-7475

20) Senthilmurugan P., Pavithra J.,Implication of social media marketing in growing healthcare industry,2014,International Journal of Applied Engineering Research,V-9,I-22,P-7448-7456

21) Loganathan R., Pavithra J.,Consumer perception towards private label brand over other brands in super markets and hypermarkets,2014,International Journal of Applied Engineering Research,V-9,I-22,P-7355-7360

22) Kerinab Beenu G., Pavithra J.,Tradeâ€"off between liquidity and profitability in logistics industry,2014,International Journal of Applied Engineering Research,V-9,I-22,P-7398-7401

23) Kerinab Beenu G., Pavithra J.,A study on the prospective consumerâ $€^{\mathrm{TM}_{\mathrm{S}}}$ perception towards utility cars in Chenna city,2014,International Journal of Applied Engineering Research,V-9,I-22,P-7526-7531

24) Pavithra J., Dilli Babu P., Ambuli T.V.,A study on budgetary control at Maruti Service Masters, Chennai,2014,International Journal of Applied Business and Economic Research,V-12,I-2,P-151-161

25) Pavithra J., Dilli Babu P., Ambuli T.V.,A study on customer satisfaction of retro Garments Pvt Ltd, Chennai,2014,International Journal of Applied Business and Economic Research,V-12,I-2,P-381-391

26) Kerinab Beenu G.H., Pavithra J., Senthilmurugan P.,A study on the influence of promotional activities for TATA ARIA among consumers in Chennai,2014,International Journal of Applied Engineering Research,V-9,I-22,P-7572-7578
27) Vijayaragavan S.P.,An investigative expert that's general FBG sensors,International Journal of Mechanical Engineering and Technology,V-8,I-8,PP-1500-1505,Y-2017

28) Vijayaragavan S.P.,Equalization routing protocol for Wi-Fi sensor strategy,International Journal of Mechanical Engineering and Technology,V-8,I-8,PP-1662-1666,Y-2017

29) Karthik B., Kiran Kumar T.V.U., Vijayaragavan P., Bharath Kumaran E.,Design of a digital PLL using 0.35 1̂1/4m CMOS technology,Middle East Journal of Scientific Research,V-18,I-12,PP-1803-1806,Y-2013

30) Kanniga E., Selvaramarathnam K., Sundararajan M.,Kandigital bike operating system,Middle - East Journal of Scientific Research, V

31) Jasmin M., Vigneshwaran T., Beulah Hemalatha S.,Design of power aware on chip embedded memory based FSM encoding in FPGA,International Journal of Applied Engineering Research,V-10,I-2,PP-4487-4496,Y-2015

32) Jasmin M.,Optimization techniques for low power VLSI circuits,Middle - East Journal of Scientific Research,V-20,I-9,PP-1082-1087,Y-2014

33) Jasmin M., Vigneswaran T.,Fuzzy controller for error control of on Chip communication,2017 International Conference on Algorithms, Methodology, Models and Applications in Emerging Technologies, ICAMMAET 2017,V-2017-January,I-,PP-1-5,Y-2017

\section{AUTHORS PROFILE}

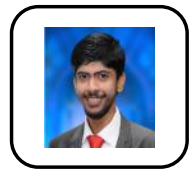

Gowtham Aashirvad Kumar,Assistant Professor, Department of Management Studies,Bharath Institute of Higher Education and Research

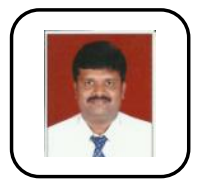

Ravikumar, Assistant Professor Department of Management Studies,Bharath Institute of Higher Education and Research

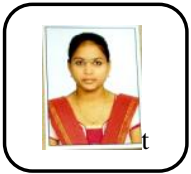

Monica Gayithiri, Student, Department of Management Studies, Bharath Institute of Higher Education and Research 